\title{
Psychology of Testimony: A Pilot Study On Accuracy Of Memory In An Emotional Vs. Neutral Situation
}

\author{
Miriam Kefauver Silva, María del Carmen Borrás Sansaloni, Alfonso Luís Palmer Pol \\ University of the Balearic Islands, Spain
}

Submission: January 05, 2018; Published: January 19, 2018

*Corresponding author: María del Carmen Borrás Sansaloni, Miriam Kefauver Silva, Alfonso Luís Palmer Pol, Department of Psychology,

University of the Balearic Islands, Spain, Email: carmen.borras@uib.es

\begin{abstract}
The present work is a pilot study on Psychology of Testimony that belongs to a wider investigation, in which from two experimental conditions; the accuracy of the subjects' recall was evaluated through a free recall test and an interrogative test. The acceptance of false information introduced in different types of questions was analyzed as well for each condition. No differences were found between the two experimental conditions regarding the number of exact details, although differences were found for the length of the statements, the number of errors, the amount of sensory details and central details, being superior in the emotional content condition than in the neutral. The results on the suggestion of misleading information, on the other hand, indicate that a high percentage of the subjects accepted the information suggested in the questions, being higher in the questions referred to the emotional condition than in the neutral condition. Due to the lack of statistical power, the results are inconclusive, although they may be useful for future research in Psychology of Testimony.
\end{abstract}

Keywords: Psychology of Testimony; Eyewitness Memory; Neutral vs. Emotional video, Accuracy of Statements; Misleading Information.

Memoria de Testigos: Un Estudio Piloto Sobre La Exactitud Del Recuerdo Ante Una Situación Emocional Vs. Neutra

El presente trabajo es un estudio piloto sobre Psicología del Testimonio perteneciente a una investigación más amplia, en el que a partir de dos condiciones experimentales, se evaluó la exactitud del recuerdo mediante una prueba de recuerdo libre y otra interrogativa. Se analizó, igualmente, la aceptación de información falsa introducida a partirse distintos tipos de pregunta. No se encontraron diferencias entre ambas condiciones experimentales, en cuanto a cantidad de detalles exactos, aunque sí en la longitud de los relatos, número de errores, cantidad de detalles sensoriales y de detalles centrales, siendo superiores en la condición de contenido emocional que en el neutro. Los resultados sobre la sugestión ante información falsa, por su parte, muestran que un alto porcentaje de los sujetos aceptaron la información introducida en las preguntas, siendo mayor en las referidas a la condición emocional que en las de contenido neutro. Debido a la falta de potencia estadística, los resultados no son concluyentes aunque pueden ser de utilidad para futuras investigaciones en el marco de la Psicología del Testimonio.

\section{Palabras Clave}

Psicología del Testimonio, Memoria de testigos, Contenido Neutro vs. Emocional, Exactitud de las declaraciones, Sugestionabilidad.
Psychology of Testimony: A Pilot Study On Accuracy Of Memory In An Emotional Vs. Neutral Situation

The Psychology of Testimony applies the human basic cognitive processes knowledge to the obtaining and evaluation of the testimonial evidence [1-7]. Often, in the absence of physical evidence, the witness' testimony is the only evidence available for the assessment of the occurrence of a criminal act. A testimony is the explanation offered by a witness or victim about a witnessed event. Consequently, it is memory evidence, in which a description of the facts and its authors or the identification of the perpetrators of the crime is made [4-6,8]. Memory is one of the fundamental basic processes of human cognition. However, and against assumptions still in force, memory is not a single faculty, but a complex set of neurological structures and interrelated systems that, in turn, interact with different cognitive processes $[1,8-10]$. Our cognitive system cannot attend to all the stimuli of the environment, so it selects the most relevant information for that moment, which is collected through the different senses. After the selection of the information, the perceptive processes are in charge of interpreting it, endowing it with meaning. From that moment the coding process takes place [11]. Memory, therefore, is understood as a complex set of systems in which constructive or coding processes of the information to be stored take place, as well as reconstructive processes, involved both in the storage and retrieval of information. In other words, the 


\section{Global Journal of Intellectual \& Developmental Disabilities}

information is subject to a continuous transformation process $[1,5,11-15]$.

Emotion influences memory, especially autobiographic memory. Traumatic memories are memories of events of great emotional impact and with a great negative emotional valence [16-18]. Some of the questions that have generated great controversy on the subject refer to:

a) if the traumatic memories differ from other types of autobiographical memories

b) if they are more or less exact than other types of autobiographical memories

c) if traumatic memories can be repressed for years or generate some type of amnesia $[16,18]$.

Regarding the first two issues, research is contradictory. While some studies indicate that traumatic memories are not so different from other autobiographical memories, others show that this type of memory is weak in terms of the amount of peripheral details, although strong concerning the amount of central details of the event [9,16-21]. It has also been observed that these memories are less accurate and more difficult to express verbally, because theyare recovered in a fragmented way andimbricated with intense feelings $[17,18,21]$. However, it has been shown that memory can be lost, modified or even created $[2,4,9,13,15,22]$. Furthermore, there is evidence that memories can be implanted in a person's memory $[2,9,15,22,23]$. All these findings reveal the limitations of the witnesses' memory; and, in any case, in a judicial context, it can be almost impossible to distinguish between real and false memories [13,23]. Also, despite the confidence of the witnesses about the accuracy of their memory, it can include a lot of wrong details. Issue with important legal implications $[9,12,15]$. Some of the ways in which false or distorted memories are elaborated are the use of suggestive techniques in therapy used by the psychologist, the formulation of suggestive questions during the interrogation of witnesses; and, even when witnesses talk to each other about what they have seen $[9,15-17,23]$. Ultimately, it seems that all types of memory are susceptible to error and to be modified, even those that we consider to be more accurate and that we will never forget.

Two types of errors can be committed in memory: those of omission, where the witness tells what happened excluding some details, either by forgetfulness or intentionally; and those of commission (distortions), where the witness introduces, either deliberately or by mistake, erroneous information about the facts $[9,12,19,22,24-26]$. Errors, on the other hand, can be intentional (lies) and unintentional, and may be due to lack of the competence to testify, to forgetfulness or to the confusion of information, and / or false memories [3,4,8, 9,12,27,26,28,29]. In order to obtain the statement, usually the narrative recovery format (or free recall test) is used, either the interrogative retrieval format (or directed recall test) [4,9,12,29-33]. In the first, given the tendency of witnesses to make very general descriptions, omission errors are common [12,29,31,34-36]. The interrogative obtaining of memory allows eliciting a greater amount of details of the event, although with more commission errors $[12,19]$. Therefore, as a previous step, the free recall test is recommended, and later more specific questions can be asked [12,19,30-32]. The questions, on the other hand, can be open or closed, the latter being more suggestive than the first $[9,12,19,21,31,32]$.The analysis of the testimony's content is based on the reality control model proposed by Johnson and Raye (1981), contemplating the logical structure of the statement; its length; the amount of exact details; the number of distortions or erroneous details; sensory details; contextual details; the amount of idiosyncratic information; allusion to mental processes; and the amount of hesitant expressions [16,24,25,28, 30-32,35-38].

To assess whether if a statement is accurate or not, factors that include those affected by the coding of the event must be taken into account: characteristics and type of event, attention conditions, duration of the event, familiarity with the event, frequency of its experimentation [4,7,9,24,28,29,35,38,39-41], factors of the witness himself (ability to testify, gender, age, level of stress, expectations, among others) [4,9,7,19,24,28$30,38,40,41]$, and, the factors that affect the retention and recovery of the event, among which the delay or time elapsed between the event and the witness's statement stand out; postevent information; multiple recovery; the previous preparation and the effect of the questions $[2,4,9,16,19,22,25,28-30,38-43]$.

On a separate issue, there is a mistaken belief that the accuracy of a statement depends on the level of confidence with which the witness expresses it. However, numerous investigations have shown that the level of confidence is independent of the accuracy of the statement $[2,9,28,32,38,42,44,45]$. Issues that, given their possible implications, legal operators should not ignore $[9,42,44]$. The present work, based on the one carried out by [37], seeks to know the accuracy of the memory of a neutral and of an emotional content event. Thus, in order to assess the accuracy of the statements, we analyze the amount of central and peripheral verbal details, as well as the amount of details about central and peripheral actions about two situations - one of neutral content and one of emotional content. In order to determine the accuracy of memory, it was also interesting to analyze the verbal content variables attending to the works of $[8,16,25,26,28,35]$. Finally, based on the work of Loftus [15], it is intended to verify if the subjects accept the misleading information provided to them as part of the events. The proposed hypotheses are:

a) The subjects will present more negative emotional responses and of higher intensity in the emotionally charged condition than in the neutral content condition.

b) On the free recall test, in the emotional content condition, a greater number of exact details described (or hit) was expected than in the neutral content condition, as well as a greater number of distortions, sensory and central details (both verbal and of actions), a greater amount of personal comments, of doubtful expressions and allusions to mental 
processes. Given the complexity of the facts presented in the emotional content condition, we also expect a greater length of the stories than in the neutral one.

c) Regarding the introduction of misleading information in both types of questions, a greater acceptance of false information is presumed in the emotional content condition than in neutral content condition. Also, we were interested in knowing the confidence of the answers.

\section{Method}

\section{Participants}

In this study, 12 subjects participated voluntarily, 10 of which (6 men and 4 women) were university or vocational training students, aged between 20 and 28 years. The other two subjects were a 40-year-oldwoman and man. Thus, 7 men and 5 women participated $($ Mage $=26.8333$; DSage $=7.9639$ ), which were assigned randomly to each experimental group (G1 and G2).

\section{Procedure}

An intra subject experimental design was used, according to which each of the subjects goes through two experimental conditions, counterbalancing their order of presentation. Both the exposure to the neutral and emotional content condition was carried out by watching a video. To G1, first, the neutral video was presented. Next, the level of emotionality was measured using the "Escala de Valoración del Estado de Ánimo" (EVEA), followed by the written free recall test; in order to evaluate the memory of what happened in the video. Subsequently, G1 answered an open question test and a multiple choice question test with 4 alternatives about the content of the video; the statement of both questions contained misleading information about the event. Finally, the subjects of G1 were presented with the emotional content video, followed by the administration of the EVEA, the corresponding free recall test, and an open question and a multiple-choice question tests. Again, both questions contained false information about the event in its statement. The participants of G2, however, in the first place, were presented with the emotional content video followed by the application of the EVEA and the memory tests described above; and, finally, the neutral content video followed by the corresponding tests. The presentation of the videos was carried out by a computer and / or a projector. For the neutral content condition, a 3' 39" subtitled mute video was used, in which a university student narrates her daily routine from the time she gets up until she goes to bed, going through different everyday academic, social and family situations, lacking emotional content. For the emotionally charged condition, we used a 6' 8" fragment of the movie "No estás sola, Sara" whose content refers to a verbal, physical and sexual aggression of the main actress by a male with whom it seems that she maintained a relationship. The actress's narration includes the explanation of her feelings and sensations during the violent episode.
In order to evaluate the emotional state after watching each video, the "Escala de Valoración del Estado de Ánimo" (EVEA) was used [46], which is composed of 16 items, measuring the current mood according to a Likert scale of 11 points (from 0 to 10). These items are grouped into 4 subscales: SadnessDepression, Anxiety, Anger-Hostility and Happiness. The evaluation of memory after watching of each video was carried out by a written free recall test, in which each subject was given a sheet of paper, which included its coding (subject number and assignment group, G1 and G2) with the following instruction: "Then, can you describe everything you remember from the video? Try to include as many details as possible, even if you do not consider them relevant". For the completion of this test, there was no time limitation; and, if needed, they were given an additional sheet. In order to assess the accuracy and quality of memory in the free recall test, a table was designed based on the experiments of García \& Migueles [37] and Manzanero \& Diges [35], in which the following response categories were taken into account: internal consistency of the statement, length of the statement, number of exact, erroneous, sensory and contextual details, allusion to mental processes, doubtful expressions, judgments or personal comments, verbal central and peripheral details of the event, and number of central and peripherals details about the actions that took place during the event. In terms of internal consistency, 1 was scored if the statement presented a logical and coherent structure, and, if not, 0 . The length of the statements was assessed according to the number of words. To the rest of the response categories, 1 point was assigned to each corresponding detail. Thus, in the sentence "Sara was wearing jeans and a white shirt" four sensory details are described.

For each experimental condition, an open question and a multiple response question with 4 response alternatives were elaborated - the fourth being: "I do not remember it" - which, in their statement, included a false element of the facts: In the neutral content condition, the open question was: At what time does the take the subway to go to the University? (The protagonist does not take the subway but the bus); and, in the emotional content condition, the following question was asked: Why does Javier slap Sara when they are in the car? (He does not slap her). Regarding the multiple-choice question, in the neutral condition, the following question was asked: Which subway line does she take? Whereas for the emotional condition the question was "What does Javier do to Sara when he lowers her skirt?" (She wears trousers). The degree of the answers confidence, on the other hand, was assessed according to a Likert scale of 5 points.

\section{Results}

The IBM SPSS version 23 has been used for data analysis. In order to know the level of emotionality subsequent to both conditions-neutral and emotional - and due to the small sample size $(n=12)$, the corresponding Wilcoxon rank tests were carried out. The exact degree of statistical significance of the test is provided. The results indicate that statistically significant 


\section{Global Journal of Intellectual \& Developmental Disabilities}

differences were found in three of the EVEA subscales between the neutral and emotional condition: subscale Sadness-Depression $(\mathrm{P}=0.005)$, subscale Anxiety $(\mathrm{P}=0.001)$, subscale Anger-Hostility $(\mathrm{P}<0.001)$ and a tendency to statistical significance was found in the Happiness subscale $(\mathrm{P}=0.089)$. The results of the SadnessDepression, Anxiety and Anger-Hostility subscales show a higher level of negative emotionality in the emotional than in the neutral condition. On the other hand, the results of the Happiness subscale show a higher level of positive emotionality in the neutral than in the emotional condition (Table 1). Regarding the analysis of the different memory categories, first of all, it should be noted that all the subjects, both from G1 and G2, showed a logical structure in their statements and in both experimental conditions.

Table 1: Mean and standard deviation values of the EVEA subscales in the neutral and emotional video

\begin{tabular}{|c|c|c|}
\hline \multicolumn{2}{|c|}{ Mean } & Standard Deviation \\
\hline \multicolumn{2}{|c|}{ Sadness-Depression Subscale } & 1.497 \\
\hline Neutral & 1.583 & 2.481 \\
\hline Emotional & 4.229 & 1.255 \\
\hline Neutral & Anxiety subscale & 2.604 \\
\hline Emotional & 1.375 & 1.094 \\
\hline Neutral & 5.625 & 2.618 \\
\hline Emotional & Anger-Hostility subscale & \\
\hline & 0.667 & 2.732 \\
\hline Neutral & 6.583 & 2.29 \\
\hline Emotional & Happiness subscale & \\
\hline
\end{tabular}

Table 2: Mean and standard deviation values of the measured categories of the free recall testing the neutral and emotional video.

\begin{tabular}{|c|c|c|}
\hline \multicolumn{3}{|c|}{ Free recall test } \\
\hline & Mean & Standard Deviation \\
\hline \multicolumn{3}{|c|}{ Length } \\
\hline Neutral video & 202.583 & 75.745 \\
\hline Emotional video & 354.167 & 136.269 \\
\hline \multicolumn{3}{|c|}{ Exact information } \\
\hline Neutral video & 6.083 & 3.538 \\
\hline Emotional video & 5.583 & 3.175 \\
\hline \multicolumn{3}{|c|}{ Distortions } \\
\hline Neutral video & 3.667 & 2.425 \\
\hline Emotional video & 6.167 & 3.512 \\
\hline \multicolumn{3}{|c|}{ Doubtful expressions } \\
\hline Neutral video & 0.333 & 0.492 \\
\hline Emotional video & 1 & 1.859 \\
\hline \multicolumn{3}{|c|}{ Allusion to mental processes } \\
\hline Neutral video & 0.167 & 0.389 \\
\hline Emotional video & 0.167 & 0.389 \\
\hline \multicolumn{3}{|c|}{ Judgments or personal comments } \\
\hline Neutral video & 1.833 & 1.528 \\
\hline Emotional video & 6.333 & 4.355 \\
\hline \multicolumn{3}{|c|}{ Sensory information } \\
\hline Neutral video & 3.083 & 4.502 \\
\hline Emotional video & 12.083 & 13.365 \\
\hline \multicolumn{3}{|c|}{ Contextual information } \\
\hline Neutral video & 12.25 & 6.398 \\
\hline Emotional video & 17.927 & 6.201 \\
\hline
\end{tabular}




\section{Global Journal of Intellectual \& Developmental Disabilities}

\begin{tabular}{|c|c|c|}
\hline \multicolumn{3}{|c|}{ Central details Verbal information } \\
\hline Neutral video & 0.417 & 0.515 \\
\hline Emotional video & 13.083 & 7.179 \\
\hline & Central details Action information & 12.802 \\
\hline Neutral video & 20.167 & 0.684 \\
\hline Emotional video & 38.167 & 0.389 \\
\hline Neutral video & Peripheral information Verbal information & 0.669 \\
\hline Emotional video & 0.167 & \\
\hline & 0.417 & 3.825 \\
\hline Neutral video & Peripheral information Action information & \\
\hline Emotional video & 2.583 & \multicolumn{2}{|c|}{3.49} \\
\hline
\end{tabular}

The results show statistically significant differences in the length of the statements $(\mathrm{P}<0.001)$, number of distortions $(\mathrm{P}=0.015)$, number of judgments or personal comments $(\mathrm{P}=0.014)$, number of sensory details $(\mathrm{P}=0.001)$, number of verbal central details of the event $(\mathrm{P}<0.001)$, and quantity of information about central actions details of the event $(\mathrm{P}<0.001)$, each response category being greater in the emotional condition than in the neutral content one. On the other hand, between both conditions no statistically significant differences were found regarding the number of correct details, number of doubtful expressions, number of allusion to mental processes, number of contextual details, and number of peripheral verbal and action details. The relationship between the recall categories was analyzed by the exact correlation test, using the 5000 Bootstrap samples procedure, which provided significant correlations between: length of the statements ( $\mathrm{r}=0.583, \mathrm{P}=0.047)$, Sensory Information $(\mathrm{r}=0.607 ; \mathrm{P}=0.036)$, Contextual Information $(\mathrm{r}=0.594 ; \mathrm{P}=0.042)$ and Peripheral Actions Details ( $\mathrm{r}=0.763$; $\mathrm{P}=0.004)$. A tendency to statistical significance was also obtained in the Central Actions details scale ( $\mathrm{r}=0.555, \mathrm{P}=0.061)$. Regarding false memory, statistical significant differences were found between both conditions in the number of hits of the open question $(\mathrm{P}=0.016)$ and in its response confidence $(\mathrm{P}=0.012)$, likewise, in the Wilcoxon tests, the signs tests and the marginal homogeneity tests, statistical differences were found between the multiple-choice question of each condition $(\mathrm{P}=0.031)$, but not between its response confidence $(\mathrm{P}=0.383)$.

On the other hand, we observed that with the introduction of false information in the wording of the open question, $66.6667 \%$ of the subjects - of G1 and G2 - accepted the information introduced in the wording as part of the event, both in the neutral and in the emotional conditions. In the multiple-answer questions related to the neutral content condition, 33,333\% of the subjects accepted the information of the wording as part of the event, and $16.6667 \%$ answered, "I do not remember it". However, in the emotional condition, the percentage of subjects who incorporated the false information of the wording as part of the event amounts to $83,333 \%$, while no subject responded not remembering it.

\section{Discussion}

The results obtained in the present work indicate that, as hypothesized, exposure to an emotionally shocking situation - such is the case of witnessing an episode of gender violence - generates a level of negative emotionality expressed in different self-reported responses (sadness-depression, anxiety and anger-hostility), regardless of the order of presentation of the experimental conditions. Regarding the content variables measured in the free recall test, it should be noted that all the subjects presented coherence and internal consistency in their statements, both for the neutral and for the emotional video, as expected. An issue that would support what was observed by Juarez [47] and Juárez, et al. [48], who observed that internal consistency, does not allow differentiating between true, false and / or contaminated fact statements. The hypothesis regarding a greater number of distortions was fulfilled, as well as a greater length of the story, amount of sensory details and central both verbal and action details, and number of personal comments for the emotional condition. However, no statistical differences were found regarding the number of correct details, the number of doubtful expressions and allusion to mental processes in relation to the neutral condition, as expected originally. It is noteworthy that the amount of exact details (or hits) did not vary depending on the emotional charge of the witnessed scenes. A question that, in part, would support the idea that traumatic memories are better remembered than neutral ones, as suggested by authors such as Yuille \& Cutshall [49].

However, as emphasized by Paz-Alonso \& Goodman [50$52]$, the memory of emotionally shocking events is not resistant to the introduction of false or suggestive information. In this regard it is worth noting that not only has a level of acceptance of misleading information been found in both conditions, being greater than expected, but also that in the emotional condition under the condition of interrogative questions, the acceptance of false information as part of the event reaches a much higher percentage than that observed in the neutral condition (more than doubled). Likewise, the level of the response confidence was significantly increased even though the "I do not remember it" option was provided, an aspect that was not contemplated 


\section{Global Journal of Intellectual \& Developmental Disabilities}

in the free recall condition. In this way and by virtue of the obtained results, it seems that the witnesses' memory about shocking events tends to be exact, although it opens the question of whether such accuracy can be expected in the case of victims. A difficult issue to be studied for ethical reasons. However, the accuracy seems to be highly compromised when false information is introduced by the evaluator, especially when the interrogative resource is used instead of free recall strategies, observing even a higher level of confidence.

This seems to have important practical implications showing that neither the accuracy nor the permeability to false information with which the witnesses can offer their recollection of a neutral event are comparable to those that were presented an emotionally shocking situation, especially when the obtaining of its memory is done through interrogative questions. The results presented in this study can help to highlight the risks of some procedures for obtaining statement by the different professionals involved in the judicial process, as well as the need for adequate custody of the statements. Furthermore, despite the evidence that memory is far from being accurate, legal operators often base their decisions on the level of witnesses' confidence when making a statement, an issue that, as has been found, does not relate with the degree of accuracy of memory.

On a separate issue, it is necessary to comment on the limitations of the present study, first of all, pointing out the small sample size, so that the data lack sufficient statistical power to be able to draw firm conclusions. Another difficulty refers to whether the experimental conditions are certainly comparable. It is possible that the duration of the videos may have had some effect on their memory. Issue that should be taken into account in later studies. However, it should be remembered that this is a pilot study with which a first approach to the memory of witnesses was intended, with special interest in the accuracy of memory and confidence of the participants, as well as in false memories.

\section{References}

1. De la Fuente J (2015) La memoria de los testigos: Oberta UOC Publishing SL, Barcelona.

2. Luna K, Migueles M (2007) Acciones y detalles en la aceptación de información postsuceso falsa y en la confianza. Estudios de Psicología 28(1): 69-81.

3. Manzanero AL (2009) Psicología Forense: Definición y técnicas. In J Bordas, JL Calvo, JL González R Magaz, AL Manzanero, et al. Teoría y práctica de la investigación criminal (pp 314-339).

4. Manzanero AL (2010a) Hitos de la historia de la psicología del testimonio en la escena internacional. Boletín de Psicología 100: 89104

5. Mira JJ, Diges M (1991a) Psicología del Testimonio: Concepto, áreas de investigación y aplicabilidad de sus resultados. Papeles del Psicólogo (48) 1-3.

6. Muñoz JM, Manzanero AL, Alcázar MA, González JL, Pérez ML, et al. (2011) Psicología Jurídica en España: Delimitación Conceptual, Campos de Investigación e Intervención y Propuesta Formativa dentro de la Enseñanza Oficial. Anuario de Psicología Jurídica 21: 3-14.
7. Scott MT, Manzanero AL (2015) Análisis del expediente judicial: Evaluación de la validez de la prueba testifical. Papeles del Psicólogo 36(2): 139-144

8. Manzanero AL (2008a) Psicología del testimonio. Una aplicación de los estudios sobre la memoria. Madrid: Ediciones Pirámide.

9. Mazzoni G (2010) ¿Se puede creer a un testigo? El testimonio y las trampas de la memoria. Madrid: Editorial Trotta, SA.

10. Papagno C (2008) La arquitectura de los recuerdos. Cómo funciona la memoria. Barcelona: Ediciones Paidós Ibérica, SA.

11. Borrás C (2012) Algunas aportaciones de la Psicología a la valoración de los delitos contra la liberated indemnidad sexual de menores. Revista de Derecho y Proceso Penal 28: 305-332.

12. Alonso-Quecuty ML (1997) Violencia y memoria de testigos. Revista Electrónica de Motivación y Emoción (REME), 12(32-33)

13. Costandi M (2013) Corruptedmemory. Nature 500(7462): 268-270.

14. Gardner M (2014) Neuroimaging and Eyewitness Testimony. Themis: Research Journal of Justice Studies and Forensic Science, 2(7): 111126.

15. Loftus E (2003) Ourchangeablememories: Legal and practicalimplications. NatureReviews Neuroscience 4(3): 231-234.

16. Manzanero AL (2010b) Recuerdo de hechos traumáticos: de la introspección al estudio objetivo. Psicopatología Clínica, Legal y Forense 10:149-164.

17. Manzanero AL, López B (2007) Características de los recuerdos autobiográficos sobre sucesos traumáticos. Boletín de Psicología 90: 7-17.

18. Manzanero AL, Recio M (2012) Memories for traumatic events: accuracy, types and characteristics. Cuadernos de Medicina Forense 18(1) 19-25.

19. Diges M, Manzanero AL (1995) El recuerdo de los accidentes de tráfico: memoria de los testigos. In L. Montoro, E Carbonell J, Sanmartín, F Tortosa (Eds), Seguridad vial: Del factor humano a las nuevas tecnologías pp 103-123.

20. Ridley AM, Clifford BR (2006) Suggestibility and state anxiety: How the two concepts relate in a source identification paradigm. Memory 14(1): 37-45.

21. Pinchanski S, Víquez EM, Zeledón CM (2004) Memorias impuestas. Medicina Legal de Costa Rica 21(2): 7-20.

22. Roediger HL, McDermott KB (2000) Tricks of Memory. American Psychological Society 9(4): 123-127.

23. Loftus EF, Davis D (2006) Recovered Memories. Annual Review of Clinical Psychology 2: 469-498.

24. Manzanero AL (1996) Evaluando el testimonio de menores testigos y víctimas de abuso sexual. Cuestiones teóricas y prácticas. Anuario de psicología juridical 6: 13-34.

25. Manzanero AL (2001a) Recuerdos reales y sugeridos: Características diferenciales. IV Congreso Iberoamericano de Psicología Jurídica 491503.

26. Manzanero AL (2004) ¿Son realmente diferentes los relatos sobre un hecho real y los sugeridos?.Anuario de Psicología Jurídica 14: 115-139.

27. Köhnken G, Manzanero AL, Scott MT (2015) Análisis de la Validez de las Declaraciones: mitos y limitaciones. Anuario de Psicología Jurídica 25: $13-19$

28. Manzanero AL, Diges M (1993) Evaluación subjetiva de la exactitud de las declaraciones de los testigos: la credibilidad. Anuario de Psicología juridical 3(1): 7-27. 
29. Manzanero AL, González JL (2015) Modelo holístico de evaluación de la prueba testifical (HELPT). Papeles del psicólogo 36(2): 125-138.

30. Aizpurua A, García-Bajos E, Migueles M (2014) ¿Quién hizo qué? Diferencias entre adultos jóvenes y mayores en la memoria para un atraco. Anales de Psicología 30(1): 308-319.

31. Arce R, Fariña F (2005) Peritación Psicológica de la Credibilidad del Testimonio, la huella psíquica y la simulación: El Sistema de Evaluación Global (SEG). Papeles del Psicólogo 26: 59-77.

32. Manzanero AL (1994) Recuerdo de sucesos complejos: efectos de la recuperación múltiple y la tarea de recuerdo en la memoria. Anuario de Psicología Jurídica 4(1): 9-23.

33. Mira JJ, Diges M (1987) Aplicación de la psicología al estudio de los procedimientos policiales de recuerdo de personas. Infancia y Aprendizaje 30: 211-219.

34. Arce R, Fariña F (2013) Psicología forense experimental. Testigos y testimonio. Evaluación cognitiva de la veracidad de testimonios y declaraciones. In S. Delgado (Dir. Tratado), S. Delgado, \& J. M. Maza Tratado de medicina legal y ciencias forenses 5: 21-46.

35. Manzanero AL, Diges M (1994) Análisis de la credibilidad de recuerdos percibidos e imaginados. Apuntes de psicología 41 y 42: 81-92.

36. Manzanero AL, Grandes I, Jódar J (2009) Edad y experiencia en el reconocimiento y la descripción de personas. Boletín de Psicología 95 87-98.

37. García E, Migueles M (1999) Memoria de testigos en una situación emocional vs neutra. Psicológica 20: 91-102.

38. Mira JJ, Diges M (1991b) Teoría Intuitivas sobre Memoria de Testigos: un examen de Metamemoria. Revista de Psicología Social 6(1): 47-60.

39. Scott MT (2014) Comentario de libros. Avances en psicología del testimonio. Gaceta de Psiquiatría Universitaria 10(1): 15-17.

40. Quereteja LM (1999) Validez y credibilidad del testimonio. La Psicología Forense Experimental. Eguzkilore (13): 157-168.

41. Scott MT, Manzanero AL, Muñoz JM, Köhnken G (2014) Admisibilidad en contextos forenses de indicadores clínicos para la detección del abuso sexual infantil. Anuario de Psicología Jurídica 24: 57-63.

This work is licensed under Creative Commons Attribution 4.0 Licens

DOI: 10.19080/GJIDD.2018.04.555633
42. Luna K, Migueles M (2007) Memoria de testigos: Patrón de distorsión de los recuerdos por la presentación de información falsa. Eguzkilore 21: 341-363.

43. Wright DB, Loftus EF, Hall M (2001) Now you see it; Now you don't: Inhibiting recall and recognition scenes. Applied Cognitive Psychology 15: 471-482.

44. Ibabe I (2000) Consideraciones metodológicas en el estudio de la relación confianza-exactitud en el ámbito de la memoria de testigos. Psicothema 12(2): 301-304.

45. Manzanero AL, López B, Contreras MJ (2011) Retrival experience as an accurate indicator of person identification in line-ups. The European Journal of Psychology Applied to Legal Context 3(2): 129-140.

46. Sanz J (2001) Un instrumento para evaluar la eficacia de los procedimientos de inducción de estado de ánimo: "La Escala de Valoración del Estado de Ánimo" (EVEA). Análisis y Modificación de Conducta 27: 71-110.

47. Juárez JR (2002) La credibilidad del testimonio infantil ante supuestos de abuso sexual: Indicadores psicosociales. Tesis doctoral de la web de la UdG.

48. Juárez JR, Mateu A, Sala E (2008) Criterios de evaluación de la credibilidad en las denuncias de violencia de género. InFJ Rodríguez, C Bringas, F Fariña, R Arce, A Bernardo (Eds). Psicología jurídica, entorno judicial y delincuencia. Tomo 5ํ․ Oviedo, España: Ediciones de la Universidad de Oviedo.

49. Yuille JC, Cutshall JL (1986) A case study of eyewitness memory of a crime. Journal of Applied Psychology 72(2): 291-301.

50. Paz-Alonso PM, Goodman GS (2008) Trauma and memory: Effects of post-event misinformation, retrieval order, and retention interval. Memory 16(1): 58-75.

51. Manzanero AL (2001) Efectos de la perspectiva sobre la exactitud y calidad de los recuerdos. Revista de psicología general y aplicada 61(3): 239-250.

52. Manzanero AL (2001b) Procedimientos de evaluación de la credibilidad de las declaraciones de menores víctimas de agresiones sexuales. Psicopatología Clínica, Legal y Forense, 1(2): 51-71.

\section{Your next submission with Juniper Publishers will reach you the below assets}

- Quality Editorial service

- Swift Peer Review

- Reprints availability

- E-prints Service

- Manuscript Podcast for convenient understanding

- Global attainment for your research

- Manuscript accessibility in different formats

( Pdf, E-pub, Full Text, Audio)

- Unceasing customer service

Track the below URL for one-step submission https://juniperpublishers.com/online-submission.php 